\title{
RNA 3 Deletion Mutants of Beet Necrotic Yellow Vein Virus Do Not Cause Rhizomania Disease in Sugar Beets
}

\author{
Tetsuo Tamada, Hirokatsu Uchino, Toshimi Kusume, and Minako Saito
}

\begin{abstract}
First author: Research Institute for Bioresources, Okayama University, Kurashiki, Okayama, 710-0046, Japan; second author: Research Center, Nippon Beet Sugar Mfg. Co., Ltd., Obihiro, Hokkaido, 080-0831, Japan; and third and fourth authors: Hokkaido Central Agricultural Experiment Station, Naganuma, Hokkaido, 069-1395, Japan.
\end{abstract}

Accepted for publication 20 July 1999.

\begin{abstract}
Tamada, T., Uchino, H., Kusume, T., and Saito, M. 1999. RNA 3 deletion mutants of beet necrotic yellow vein virus do not cause rhizomania disease in sugar beets. Phytopathology 89:1000-1006.

Two mutant strains of beet necrotic yellow vein virus (BNYVV) containing deletions in RNA 3 were obtained by single lesion transfers in Tetragonia expansa. The deleted regions encode either 94 or 121 amino acids toward the C-terminal part of the 25-kDa protein (P25). Wild-type and mutant virus strains were inoculated by Polymyxa betae to sugar beet seedlings of susceptible and partially resistant cultivars. No differences were found in virus content in rootlets between mutant and wild-type viruses or between susceptible and resistant cultivars after culture for 4 weeks in a growth cabinet. However, when virus-inoculated seedlings were grown

in the field for 5 months, the wild-type virus caused typical rhizomania root symptoms (69 to $96 \%$ yield loss) in susceptible cultivars, but no symptoms (23\% loss) developed in most plants of the resistant cultivar, and BNYVV concentrations in the roots were 10 to $20 \times$ lower in these plants than in susceptible plants. In contrast, the mutant strains caused no symptoms in susceptible or resistant cultivars, and the virus content of roots was much lower in both cultivars than in wild-type virus infections. Wild-type RNA 3 was not detectable in most of the taproots of a resistant cultivar without any symptoms, suggesting that replication of undeleted RNA 3 was inhibited. These results indicate that the P25 of BNYVV RNA 3 is essential for the development of rhizomania symptoms in susceptible cultivars and suggest that it may fail to facilitate virus translocation from rootlets to taproots in the partially resistant cultivar.
\end{abstract}

Rhizomania is a severe disease of sugar beet caused by beet necrotic yellow vein virus (BNYVV), which is transmitted by the soilinhabiting pathogen Polymyxa betae $(15,19)$. The disease is now distributed in many sugar beet-growing countries and is economically very important, not only because it causes a severe loss in root yield and sugar content but also because it is difficult to control $(1,14,19)$. In field-infected sugar beet, BNYVV is usually confined to the roots. Symptoms of virus infection are characterized by a massive proliferation of the lateral rootlets of taproots and other abnormalities.

Genetic resistance is the most promising approach for the control of rhizomania, and selection of lines that are resistant or tolerant to the disease has become a major objective in sugar beet breeding programs in Europe, the United States, and Japan (1). The first lines with some resistance to rhizomania were derived from material that had been selected for resistance to the Cercospora leaf spot pathogen in northern Italy (3). Selection and evaluation of these resistant lines have been done mostly on the basis of their performance in the field, in which resistance or tolerance is indicated by yield relative to a susceptible standard line. In recent years, several resistant cultivars, such as Rizor, have been developed and are now grown in rhizomania-infested regions of continental Europe and other countries $(1,14)$. The resistance of such cultivars has been reported to be caused by a restriction of virus multiplication, translocation in the roots, or both, but not by resistance to infection by the vector $P$. betae $(2,4,5,12,13,18,25)$.

The genome of BNYVV consists of five plus-strand RNA components $(15,19)$. BNYVV RNAs 1 and 2 encode proteins involved in replication, assembly, and cell-to-cell movement. RNAs 3, 4, and

Corresponding author: T. Tamada; E-mail address: ttamada@rib.okayama-u.ac.jp

Publication no. P-1999-0908-01R

(C) 1999 The American Phytopathological Society
5 are not required for mechanical infection on leaves of host plants. RNAs 3 and 4 are always present in field isolates, and both are needed for disease development and spread in nature: RNA 3 is involved in rhizomania symptoms of sugar beet, whereas RNA 4 is important for $P$. betae-mediated transmission of the virus (20). RNA 5 is not present in all virus sources, but it has been reported in some Japanese, Chinese, and French isolates $(8,11,24)$. It is associated with the severity of symptom development in sugar beet roots (22).

In previous work, we have shown by inoculation tests using the vector $P$. betae that BNYVV isolates with RNA 3 caused a massive proliferation of fine rootlets and a severe reduction of sugar content in taproots in the glasshouse, but isolates lacking RNA 3 caused no visible symptoms, although there was a slight reduction in root weight $(7,23)$. Furthermore, Koenig et al. (9) have used mechanical inoculation to young sugar beet seedlings with inocula containing transcript-derived RNAs 3 and 4 to show that the presence of RNA 3 was associated with a greatly increased virus titer in taproots and with a severe yield reduction. These results strongly suggest that BNYVV RNA 3 facilitates the multiplication and spread of the virus in root tissue and may have a major role in the production of rhizomania symptoms.

In this study, we have tested BNYVV strains containing either wild-type RNA 3 or an RNA 3 deletion mutant for their effects on symptom development and sugar yield in susceptible and partially resistant cultivars under laboratory and field conditions. The results show that the $25-\mathrm{kDa}$ protein (P25) encoded by RNA 3 is directly responsible for the development of rhizomania symptoms on susceptible sugar beet cultivars, and also that it may inhibit virus translocation from rootlets to taproots in the partially resistant cultivar.

\section{MATERIALS AND METHODS}

Virus isolation, propagation, and inoculation. The laboratory isolates S-34 and T-34 (RNA-1+2+3+4), S-3 and T-3 (RNA-1+2+3), 
and S-4 and T-4 (RNA-1+2+4) were used as described by Tamada et al. (24) (Table 1, Fig. 1). These laboratory isolates were obtained from individual field isolates $\mathrm{S}$ and $\mathrm{T}$ by single-lesion transfer in Tetragonia expansa leaves. The isolates containing RNA 3 deletion mutants ( $\mathrm{S}-3 \mathrm{c}$ and $\mathrm{T}-3 \mathrm{~d}$ ) were also produced by successive mechanical transfers into $T$. expansa leaves. The virus isolates were propagated in inoculated $T$. expansa leaves in a glasshouse. Leaf extracts for use as virus inoculum were made in $0.1 \mathrm{M}$ phosphate buffer, $\mathrm{pH} 7.4$, containing $0.5 \%$ 2-mercaptoethanol. T. expansa and Beta macrocarpa were used as tests plants to assess pathogenicity of the mutants isolated.

Extraction and analysis of viral RNA. The virus particles were purified from inoculated $T$. expansa leaves as described by Tamada et al. (24). Purified virus was dissociated in $2 \%$ sodium dodecyl sulfate (SDS); $30 \mathrm{mM}$ sodium phosphate, $\mathrm{pH} 7.2$; and $1 \mathrm{mM} \mathrm{Na} \mathrm{EDTA}_{2}$ at $60^{\circ} \mathrm{C}$ for $5 \mathrm{~min}$. Protein was removed by phenol extraction, and RNA was precipitated by ethanol at $-80^{\circ} \mathrm{C}$ and pelleted by centrifugation. Viral RNAs were analyzed by agarose gel electrophoresis as described by Tamada et al. (24) or northern blot hybridization tests using digoxigenin-labeled DNA probes specific to each of RNAs 3, 4, and 5 (17). RNA samples for northern blot hybridization were prepared from total nucleic acids from inoculated T. expansa leaves, but those were prepared from virus particles purified partially from rootlets or taproots of sugar beet plants as described by Saito et al. (17). In the case of rootlets, 0.2 to $1 \mathrm{~g}$ of root tissue was ground with a pestle and mortar in $0.5 \mathrm{M}$ sodium borate buffer, $\mathrm{pH}$. 9.0, containing $1 \mathrm{mM}$ $\mathrm{Na}_{2}$ EDTA. After a low-speed centrifugation, the supernatant was added to $2 \%$ Triton $\mathrm{X}-100$, followed by a high-speed centrifugation (Centrikon TFT 70.38 rotor at 92,000 $\times g$ for $90 \mathrm{~min}$; Kontron AG, Zurich, Switzerland). The resulting pellet was resuspended in distilled water $\left(200 \mu \mathrm{l} / \mathrm{g}\right.$ of tissue) and was frozen at $-20^{\circ} \mathrm{C}$ until use. Virus content in the taproots was much lower than in the rootlets; therefore, 20 to $40 \mathrm{~g}$ of each taproot tissue was first grated with a grater and then ground with a pestle and mortar. The final pellet was resuspended in 10 to $50 \mu \mathrm{l}$ of distilled water per $1 \mathrm{~g}$ of tissue, depending on the virus concentration in taproots.

Cloning and sequencing. The nucleotide sequences of the coding region of RNA 3 deletion mutants were determined as described by Saito et al. (16). Total nucleic acids were extracted by phenol method from inoculated leaves of $T$. expansa. First-strand cDNA was synthesized using a commercial kit (Amersham cDNA synthesis kit; Amersham Corp., Arlington Heights, IL) according to the manufacturer's instructions. cDNAs were amplified by reverse transcriptase-polymerase chain reaction (RT-PCR) using the specific upstream primer 3B (5'-CGAATTCATGGGTGATATATTA$3^{\prime}$ ), representing RNA 3 nucleotides 442 to 458 (EcoRI site underlined), and the downstream primer 3D (5'-GTGATAACTCT-

TABLE 1. Symptoms produced in two host species by beet necrotic yellow vein virus isolates containing different combinations of RNA 3, RNA 4, or RNA 3 mutants

\begin{tabular}{lccccc}
\hline & & \multicolumn{2}{c}{ Tetragonia expansa } & & \multicolumn{2}{c}{ Beta macrocarpa } \\
\cline { 5 - 6 } \cline { 5 - 6 } Isolate & RNA components & $\mathrm{I}^{\mathrm{a}}$ & & $\mathrm{I}$ & \multicolumn{1}{c}{$\mathrm{S}$} \\
\hline S-34 & $1+2+3+4$ & YS $^{\mathrm{b}}$ & & YS & YM, ST \\
S-3 & $1+2+3$ & YS & & YS & YM, ST \\
S-4 & $1+2+4$ & CS & & fCS & O \\
S-3c & $1+2+3 \mathrm{c}$ & CS & & fCS & (M) \\
S-3c 4 & $1+2+3 \mathrm{c}+4$ & SCS & & CS & (M) \\
T-34 & $1+2+3+4$ & YS & & YS & YM, ST \\
T-3 & $1+2+3$ & YS & & YS & YM, ST \\
T-4 & $1+2+4$ & CS & & fCS & O \\
T-3d & $1+2+3 d$ & CS & fCS & (M) \\
T-3d & $1+2+3 d+4$ & SCS & CS & (M) \\
\hline
\end{tabular}

${ }^{\mathrm{a}} \mathrm{I}=$ inoculated leaves and $\mathrm{S}=$ systemically infected leaves.

${ }^{\mathrm{b}} \mathrm{YS}=$ yellow spots, $\mathrm{CS}=$ chlorotic spots, $\mathrm{sCS}=$ severe chlorotic spots, $\mathrm{fCS}=$ faint chlorotic spots, $\mathrm{YM}=$ yellow mosaic or mottle, $\mathrm{ST}=$ stunting, $\mathrm{M}=$ mild mottle, and $\mathrm{O}=$ not infected; parentheses indicate symptoms produced occasionally.
AATC-3'), complementary to RNA 3 nucleotides 1,098 to 1,112 (Fig. 2). PCR amplifications were for 35 cycles of $1 \mathrm{~min}$ at $94^{\circ} \mathrm{C}$ for denaturation, annealing for $1 \mathrm{~min}$ at $50^{\circ} \mathrm{C}$, and synthesis for $2 \mathrm{~min}$ at $72^{\circ} \mathrm{C}$ (Program Temp Control System PC-700; Astec, Fukuoka, Japan). The PCR products were ligated into a pUC119 and transformed into Escherichia coli strain NM522 (Stratagene Inc., La Jolla, CA). Nucleotide sequences of selected clones were determined with an Applied Biosystems 373A automatic sequencer (Applied Biosystems, Inc., Foster City, CA). Sequence data were assembled and analyzed using GENETYX-MAC (SDC, Tokyo).

Detection of BNYVV. BNYVV infection and virus content in sugar beet roots were determined by enzyme-linked immunosorbent assay (ELISA) (20). The BNYVV content of root extracts was calculated by interpolating the absorbance on a plot of absorbance against concentration of purified virus.

Inoculation using $\boldsymbol{P}$. betae. Isolate $\mathrm{P}-1$ of virus-free $P$. betae was maintained in roots of sugar beet seedlings (Beta vulgaris $\mathrm{cv}$. Starhill) and kept as resting spores in dried rootlets (20). P. betae cultures carrying each BNYVV isolate were produced as described by Tamada and Kusume (21) and maintained in rootlets of sugar beet seedlings. Unless otherwise stated, sugar beet seedlings were used as test plants for transmission tests by $P$. betae. They were grown in special test tubes $(24 \mathrm{~mm}$ wide and $120 \mathrm{~mm}$ long with a drainage hole) filled with quartz sand. The seedlings were supplied every day with modified Hoagland and Arnon solution, $\mathrm{pH}$ 7.0,
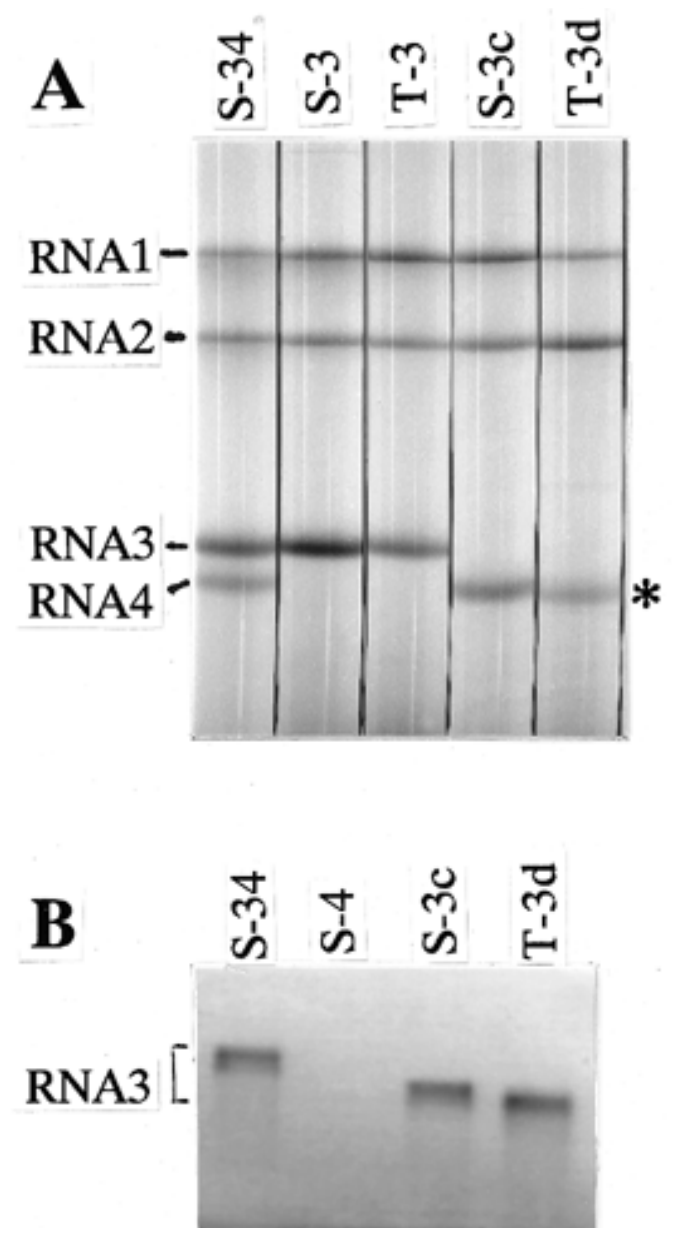

Fig. 1. A, Agarose gel electrophoresis of beet necrotic yellow vein virus (BNYVV) RNA from isolates S-34 (RNA-1+2+3+4), S-3 (RNA-1+2+3), T-3 (RNA-1+2+3), S-3c (RNA-1+2+3c), and T-3d (RNA-1+2+3d). RNA was prepared from virus particles purified from Tetragonia expansa leaves as described by Tamada et al. (24). Asterisk indicates the position of deleted RNA 3. The gels were stained with $0.005 \%$ stains-all (Eastman Kodak, Rochester, NY) in 50\% formamide. B, Northern blot hybridization for the detection of RNA 3 in BNYVV isolates S-34, S-4 (RNA-1+2+4), S-3c, and T-3d. Digoxigeninlabeled DNA probe specific to RNA 3 was used (17). 
and grown in a growth cabinet at $25^{\circ} \mathrm{C}$ with a 16 -h light and 8 -h dark cycle (24). Seedlings were inoculated by pouring the crude homogenate of infected rootlets or zoospore suspensions into test tubes containing the seedlings. For zoospore inoculation, a zoospore suspension was obtained by collecting water drained from the bottom of test tubes into which nutrient solution had been poured. Virus inoculation was done by pouring zoospore suspensions of viruliferous $P$. betae onto sugar beet seedlings grown in test tubes in a growth cabinet or grown in paper pots in the glasshouse.

Field tests. The four sugar beet cultivars used for field tests were Monomidori (highly susceptible), Monohikari and Ema (susceptible), and Rizor (partially resistant). Sugar beet seeds were sown in paper pots containing sterilized soil and fertilizer, and the seedlings were grown in the glasshouse. Virus inoculation was done by pouring zoospore suspensions of individual virus-carrying $P$. betae onto sugar beet seedlings grown in paper pots. Each experiment included a control treatment of seedlings in which virus-free $P$. betae was inoculated at the same time. Virus-inoculated and noninoculated control seedlings were transplanted to the field on the end of May and were cultivated in accordance with the standard commercial practice of Hokkaido (10). Forty-eight seedlings were used per plot, and experiments were arranged in randomized plots with two replicates. To reduce the effect of infected plants between plots, healthy plants were planted between test plots. Plants were harvested at the end of October, and groups of 40 roots per plot were tested for symptoms, virus content, yield parameters (root yield, sugar content, and sugar yield), and quality parameters ( $\mathrm{Na}, \mathrm{K}$, and $\alpha$-amino nitrogen; mmol/100 $\mathrm{g}$ of beet).

\section{RESULTS}

Production of deletion mutants of RNA 3. BNYVV RNAs 2, 3,4 , and 5 may undergo deletion by being passed serially by me- chanical inoculation of Chenopodium quinoa or T. expansa $(15,19$, 21,24). We tried to produce deletion mutants of RNA 3 in the same way. Single-lesion isolates from two field isolates, $\mathrm{S}$ and $\mathrm{T}$, were passed serially by mechanical inoculation to $T$. expansa leaves, and the RNAs extracted from virus particles isolated from inoculated leaves were analyzed by agarose gel electrophoresis and northern blot hybridization. Single-lesion isolates that contained deleted RNA 3, originally derived from isolates $\mathrm{S}$ and $\mathrm{T}$, will be referred to as S-3c (RNA-1+2+3c) and T-3d (RNA-1+2+3d), respectively (Fig. 1). The wild-type RNA 3 was 1.8 kilobases $(\mathrm{kb})$ in length, whereas two deleted RNA 3 forms (RNAs $3 \mathrm{c}$ and $3 \mathrm{~d}$ ) were $\approx 1.6$ and $1.55 \mathrm{~kb}$ in length, respectively, and hybridized with cDNA probe to RNA 3 (Fig. 1B), but not to RNA 4 or RNA 5 (data not shown).

Sequence analysis of deleted RNA 3. Sequence analysis revealed that the deleted regions of RNAs $3 \mathrm{c}$ and $3 \mathrm{~d}$ were from nucleotide positions 726 to 1,088 (363 nucleotides [nt]) and from positions 717 to 998 (282 nt), respectively (Fig. 2A). The deletion sites in both mutants were thus in the coding region (nucleotides 445 to 1,101) of the P25, and the RNAs 3c and 3d lost 121 and 94 amino acid residues, respectively, toward the C-terminal part of the P25 (Fig. 2B). The nucleotide sequence of RNA 3c was the same as that of RNA 3 of isolate $\mathrm{S}$ as reported by Saito et al. (16), except for the deletion. Comparison of RNA 3 in S-3 and T-3 isolates revealed 11 amino acid changes $(5.0 \%)$ in the $\mathrm{P} 25$ open reading frames $(\mathrm{ORF})$ in regions that were not deleted in one or the other isolate (Fig. 2B).

Pathogenicity of RNA 3 deletion mutants. In inoculated leaves of T. expansa, S-3c or T-3d caused chlorotic spots, as did S-4 or T-4 (RNA-1+2+4), whereas S-3 or T-3 (RNA-1+2+3) induced bright yellow spots (Table 1) (24). In B. macrocarpa, mutant strain S-3c or T-3d caused chlorotic lesions in inoculated leaves and later produced systemic mild mottle in some plants, whereas isolate S-3 or $\mathrm{T}-3$ caused yellow lesions in inoculated leaves, followed by severe

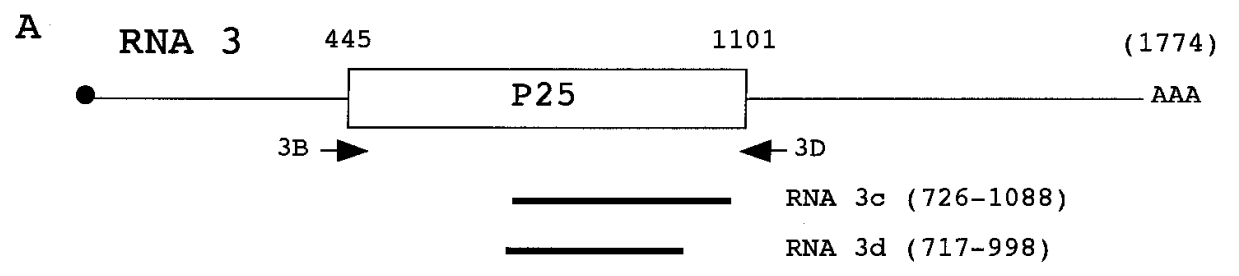

B

1

60

S-3 MGDILGAVYDLGHRPYLARRTVYEDRLILSTHGNVCRAINLLTHDNRTTLVYHNNTKRIR

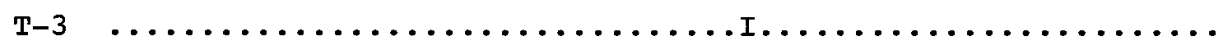

61

120

FRGLLCAYRVPYCGFRALCRVMLCSLPRLCDIPINGSRDFVADPTRLDSSVNELLVSNGL

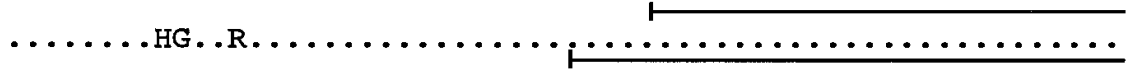

VTHYDRVHNVPIHTDGFEVVDFTTVFRGPGNFLLPNATNFPRSTTTDQVYMVCLVNTVNC . . ........ . . . . . . . . . . . . . . . . . . . . . . D.

Fig. 2. A, Genetic map of beet necrotic yellow vein virus RNA 3 and the deleted regions of two RNA 3 mutants (RNAs $3 c$ and $3 d$ ). Box indicates the open reading frame. Arrows indicate the positions of the primers for polymerase chain reaction. Thick lines indicate the deleted regions. B, Alignment of the amino acid sequences of the open reading frame of RNA 3 in S-3 and T-3 isolates. Dots indicate amino acids identical to RNA 3 of isolate S-3 as reported by Saito et al. (16). Underlines indicate that the residue is absent. 
systemic infection (Table 1) (24). Thus, the mutants RNAs 3c and $3 \mathrm{~d}$, in which about half of the P25 ORF was deleted, caused much milder symptoms in T. expansa and B. macrocarpa, as described by Jupin et al. $(6,7)$. In addition, no differences were found in symptom expression between S-3 and T-3 or between S-4 and T-4 (Table 1).

BNYVV RNA 4 is required for efficient transmission of the virus by $P$. betae (20); therefore, a new mutant strain containing RNA 4 was produced by inoculating mixtures of $\mathrm{S}-3 \mathrm{c}$ and $\mathrm{S}-4$ or T-3d and T-4 onto T. expansa leaves, as described by Tamada and Kusume (21), for use in transmission tests by $P$. betae. These new isolates are referred to as S-3c4 (RNA-1+2+3c+4) and T-3d4 (RNA-1+2+3d+4). Symptoms produced in two hosts by these mixed isolates were slightly more severe than those produced by each isolate alone (Table 1).

Transmissibility of RNA 3 deletion mutants. Transmission efficiencies of $P$. betae cultures carrying the aforesaid RNA 3 deletion mutants were compared with those of other $P$. betae cultures carrying S-34, S-4, or T-34. Sugar beet seedlings (two- to three-leaf stage) were inoculated with the crude homogenate of rootlets infected with the virus-carrying $P$. betae. At 37 days after inocula- tion, virus infection and virus concentration in rootlets of these sugar beet seedlings were tested by ELISA. The tests revealed that all 20 seedlings inoculated with each virus isolate were infected, and the mean concentrations of virus (per gram of fresh tissue) were as follows: S-4, $23 \mu \mathrm{g}$; S-3c4, $85 \mu \mathrm{g}$; T-3d4, $100 \mu \mathrm{g}$; S-34, $125 \mu \mathrm{g}$; and $\mathrm{T}-34,172 \mu \mathrm{g}$. Thus, the virus concentration in rootlets inoculated with the mutant strains was slightly lower than in rootlets inoculated with the wild-type strains, but was much higher than in rootlets inoculated with the isolate S-4. Northern blot hybridization confirmed that the rootlets of sugar beet seedlings infected with S-3c4 or T-3d4 always contained RNA 3c or RNA 3d (data not shown). In addition, other inoculation experiments using dried resting spores of $P$. betae showed that the deleted RNA 3, when present together with RNA 4, is stable and transmitted by $P$. betae as efficiently as the wild-type strains (data not shown).

Effect of symptom development and virus content. The first experiment was done to test the effect of the mutant and wild-type strains on symptom development and virus concentration in roots of different sugar beet cultivars. Zoospore suspensions of $P$. betae that carried S-3c4, T-3d4, or S-34 were inoculated to the seedlings of the susceptible cv. Monomidori and the partially resistant cv.

TABLE 2. Effect of beet necrotic yellow vein virus (BNYVV) RNA 3 deletion mutants on symptoms and virus content in roots of sugar beet plants grown for 28 days in sand culture or 5 months in the field

\begin{tabular}{|c|c|c|c|c|c|c|}
\hline \multirow[b]{2}{*}{ BNYVV isolate } & \multirow[b]{2}{*}{ Cultivar ${ }^{\mathrm{a}}$} & \multicolumn{2}{|r|}{ Sand culture } & \multicolumn{3}{|c|}{ Field } \\
\hline & & Detection $^{\mathrm{b}}$ & Virus content in rootlets ${ }^{c}$ & Root symptoms & Detection $^{\mathrm{b}}$ & Virus content in taproot tips ${ }^{\mathrm{c}}$ \\
\hline \multirow[t]{2}{*}{$\overline{\mathrm{S}-3 \mathrm{c} 4 \text { (deletion mutant) }}$} & Susceptible & $18 / 18$ & 130 & - & $32 / 32$ & $0.86(0.08-3.20)$ \\
\hline & Partially resistant & $18 / 18$ & 120 & - & $32 / 32$ & $0.42(0.16-2.10)$ \\
\hline \multirow[t]{2}{*}{$\mathrm{T}-3 \mathrm{~d} 4$ (deletion mutant) } & Susceptible & $18 / 18$ & 210 & - & $32 / 32$ & $0.62(0.24-1.72)$ \\
\hline & Partially resistant & $18 / 18$ & 180 & - & $32 / 32$ & $0.28(0.08-0.78)$ \\
\hline \multirow[t]{3}{*}{ S-34 (wild-type strain) } & Susceptible & $18 / 18$ & 230 & + & $10 / 10^{\mathrm{d}}$ & $4.68(1.15-9.40)$ \\
\hline & Partially resistant & $18 / 18$ & 160 & + & $5 / 5$ & $2.80(1.18-6.40)$ \\
\hline & & & & - & $19 / 27$ & $0.24(0.08-0.76)$ \\
\hline
\end{tabular}

a Susceptible cv. Monomidori and partially resistant cv. Rizor.

b Number of sugar beet roots in which the virus was detected/number tested.

c Values ( $\mu \mathrm{g}$ of virus per $\mathrm{g}$ of fresh root tissue) are means with the range in parentheses.

d A total of 22 out of 32 plants died.

TABLE 3. Effect of beet necrotic yellow vein virus (BNYVV) RNA 3 deletion mutant and wild type on the yield and virus detection in roots of sugar beet plants grown in the field

\begin{tabular}{|c|c|c|c|c|c|c|c|c|}
\hline Cultivar $^{\mathrm{a}}$ & Virus isolate $^{\mathrm{b}}$ & $\begin{array}{c}\text { Root } \\
\text { symptoms }\end{array}$ & $\begin{array}{c}\text { Root yield } \\
\text { (g/root) }\end{array}$ & $\begin{array}{c}\text { Sugar content } \\
(\%)\end{array}$ & $\begin{array}{c}\text { Sugar yield } \\
\text { (g/root) }\end{array}$ & $\begin{array}{c}\text { Relative sugar } \\
\text { yield (\%) }\end{array}$ & Detection $^{\mathrm{d}}$ & $\begin{array}{c}\text { Virus content } \\
\text { in taproot tips }\end{array}$ \\
\hline Monomidori & $\begin{array}{l}\mathrm{S}-4 \\
\mathrm{~T}-3 \mathrm{~d} 4 \\
\mathrm{~T}-34 \\
\text { Noninoculated } \\
\text { LSD 5\% } \mathrm{f}\end{array}$ & $\begin{array}{l}- \\
- \\
+++ \\
-\end{array}$ & $\begin{array}{l}785 \\
761 \\
102 \\
783 \\
125\end{array}$ & $\begin{array}{r}15.3 \\
15.5 \\
5.2 \\
15.7 \\
1.5\end{array}$ & $\begin{array}{r}120 \\
118 \\
5 \\
122 \\
24\end{array}$ & $\begin{array}{r}98 \\
97 \\
4 \\
100 \\
25\end{array}$ & $\begin{array}{c}24 / 24(100) \\
36 / 36(100) \\
8 / 8(100) \\
0 / 10(0)\end{array}$ & $\begin{array}{l}0.3 \\
0.7 \\
3.2 \\
0 \\
0.8\end{array}$ \\
\hline Monohikari & $\begin{array}{l}\text { S-4 } \\
\text { T-3d4 } \\
\text { T-34 } \\
\text { Noninoculated } \\
\text { LSD 5\% }\end{array}$ & $\begin{array}{l}- \\
- \\
++ \\
-\end{array}$ & $\begin{array}{r}878 \\
869 \\
279 \\
865 \\
64\end{array}$ & $\begin{array}{r}16.4 \\
16.6 \\
10.9 \\
16.2 \\
1.0\end{array}$ & $\begin{array}{r}144 \\
144 \\
30 \\
140 \\
14\end{array}$ & $\begin{array}{r}103 \\
103 \\
22 \\
100 \\
12\end{array}$ & $\begin{array}{c}24 / 24(100) \\
34 / 36(94) \\
36 / 36(100) \\
0 / 10(0)\end{array}$ & $\begin{array}{l}0.5 \\
0.6 \\
7.0 \\
0 \\
2.4\end{array}$ \\
\hline Ema & $\begin{array}{l}\text { S-4 } \\
\text { T-3d4 } \\
\text { T-34 } \\
\text { Noninoculated } \\
\text { LSD 5\% }\end{array}$ & $\begin{array}{l}- \\
- \\
++ \\
-\end{array}$ & $\begin{array}{r}861 \\
834 \\
318 \\
880 \\
66\end{array}$ & $\begin{array}{r}16.2 \\
16.4 \\
13.7 \\
16.0 \\
1.0\end{array}$ & $\begin{array}{r}139 \\
137 \\
44 \\
141 \\
12\end{array}$ & $\begin{array}{r}99 \\
97 \\
31 \\
100 \\
10\end{array}$ & $\begin{array}{c}23 / 24(96) \\
35 / 36(97) \\
36 / 36(100) \\
0 / 10(0)\end{array}$ & $\begin{array}{l}0.4 \\
0.4 \\
4.0 \\
0 \\
1.8\end{array}$ \\
\hline
\end{tabular}

a Monomidori $=$ highly susceptible, Monohikari $=$ susceptible, Ema $=$ susceptible, and Rizor $=$ partially resistant .

b RNA content: S-4 (RNA-1+2+4), T-3d4 (RNA-1+2+3d+4), and T-34 (RNA-1+2+3+4).

$\mathrm{c}+,++$, and +++ indicate severity of rhizomania symptoms; - indicates no symptoms. In parenthesis, symptoms appeared in a few cases.

${ }^{\mathrm{d}}$ Number of sugar beet roots in which the virus was detected/number tested. Parentheses indicate percent BNYVV detection.

e Measures in $\mu \mathrm{g}$ of virus per $\mathrm{g}$ of tissue.

${ }^{\mathrm{f}}$ Least significant difference; ns indicates no significantly different at $5 \%$ level. 
Rizor, which were grown in special tests tubes in the growth cabinet. At 28 days after inoculation, virus infection in rootlets of individual seedlings was examined by ELISA. All inoculated seedlings were infected with BNYVV, and no significant differences in virus concentrations in the rootlets of sugar beet seedlings were found either between mutant and wild-type strains or between susceptible and partially resistant cultivars (Table 2). The wild-type virus caused symptoms of abnormal proliferation in rootlets of all seedlings of the susceptible cultivar and some of the partially resistant cultivar, but the two mutant strains did not induce such symptoms.

In further experiments, 32 virus-inoculated seedlings of each cultivar were transplanted to soil and grown in the field for 5 months. Plants were harvested, and the concentration of BNYVV in taproots was examined by ELISA. Samples were extracted from near the tip of the main roots, because the virus concentration is somewhat greater there than in the center of taproots (23). When the plants were inoculated with wild-type virus, all of the susceptible plants showed typical foliage and root symptoms, and most of them ( 22 out of 32 plants) died during the growing season. On the other hand, out of 32 plants of the partially resistant cultivar, 5 showed foliage and root symptoms similar to those in the surviving plants of the susceptible cultivar, but the other 27 showed no root symptoms, although the virus was detected by ELISA in 19 taproots (Table 2). In addition, considerable variation in virus content was found from plant to plant. Thus, it appears that both resistant and susceptible plants were present in the population of cv. Rizor, indicating that there are differences in resistance (susceptibility) between plants within a cultivar (12). The mean concentration of virus in taproots of the resistant plants was 10 to $20 \times$ lower than the virus concentration in taproots of susceptible plants (Table 2).

In contrast, the two mutant strains S-3c4 and T-3d4 caused no foliage or root symptoms in plants of either susceptible or partially resistant cultivars. Virus was detected in the taproots of all plants inoculated, and the concentrations in taproots of susceptible plants were about twice those in taproots of resistant plants (Table 2). However, the mutant virus contents in taproots were about $10 \times$ less

TABLE 4. Detection of BNYVV RNAs 3 and 4 by northern blot hybridization in individual roots of sugar beet plants inoculated with RNA 3 deletion mutant and wild-type virus

\begin{tabular}{|c|c|c|c|c|c|}
\hline \multirow[b]{2}{*}{ Cultivar ${ }^{\mathrm{a}}$} & \multirow{2}{*}{$\begin{array}{l}\text { Virus } \\
\text { isolate }\end{array}$} & \multirow{2}{*}{$\begin{array}{c}\text { Root } \\
\text { symptoms }\end{array}$} & \multirow{2}{*}{$\begin{array}{l}\text { Virus } \\
\text { content }^{\mathrm{c}}\end{array}$} & \multicolumn{2}{|c|}{ Northern blot hybridization ${ }^{\mathrm{d}}$} \\
\hline & & & & RNA 3 & RNA 4 \\
\hline \multirow[t]{7}{*}{ Monomidori } & S-4 & - & ++ & - & + \\
\hline & S-4 & - & + & - & + \\
\hline & S-4 & - & ++ & - & - \\
\hline & $\mathrm{T}-3 \mathrm{~d} 4$ & - & ++ & $++(*)$ & ++ \\
\hline & $\mathrm{T}-3 \mathrm{~d} 4$ & - & ++ & $++(*)$ & + \\
\hline & T-34 & + & +++ & +++ & ++ \\
\hline & $\mathrm{T}-34$ & + & +++ & +++ & ++ \\
\hline \multirow[t]{13}{*}{ Rizor } & $\mathrm{T}-3 \mathrm{~d} 4$ & - & ++ & $++(*)$ & ++ \\
\hline & $\mathrm{T}-3 \mathrm{~d} 4$ & - & + & $+(*)$ & + \\
\hline & $\mathrm{T}-3 \mathrm{~d} 4$ & - & +++ & $+\left({ }^{*}\right)$ & - \\
\hline & $\mathrm{T}-34$ & + & +++ & +++ & ++ \\
\hline & $\mathrm{T}-34$ & + & ++ & ++ & ++ \\
\hline & $\mathrm{T}-34$ & - & + & - & ++ \\
\hline & $\mathrm{T}-34$ & - & + & - & ++ \\
\hline & $\mathrm{T}-34$ & - & + & - & + \\
\hline & $\mathrm{T}-34$ & - & + & - & + \\
\hline & $\mathrm{T}-34$ & - & + & - & - \\
\hline & $\mathrm{T}-34$ & - & + & - & - \\
\hline & T-34 & - & - & - & - \\
\hline & T-34 & - & - & - & - \\
\hline
\end{tabular}

${ }^{a}$ Monomidori is highly susceptible and Rizor is partially resistant.

$\mathrm{b}+$ Indicates typical rhizomania symptoms and - indicates no symptoms.

${ }^{c}$ Virus content ( $\mu \mathrm{g} / \mathrm{g}$ of root tissue) was $>3.0(+++), 3.0-0.4(++)$, and $<0.3(+)$.

${ }^{\mathrm{d}}$ RNA samples for northern blot hybridization were prepared from taproot tips. Hybridization signals were strong $(+++)$, moderate $(++)$, weak $(+)$, and negative $(-) .(*)=$ Short-sized signal. than those in plants infected with wild-type virus (Table 2). Both deletion mutants, $\mathrm{S}-3 \mathrm{c} 4$ and T-3d4, behaved in a similar manner.

Thus, a large difference was found between susceptible and partially resistant cultivars when the roots of sugar beet plants inoculated with wild-type BNYVV had matured. In most, but not all, plants of the partially resistant cultivar, BNYVV seemed to have difficulty in moving from the rootlets, which the virus infects when young, to the main taproots. In susceptible plants, however, the virus was able to move easily to the main taproots.

Effect on sugar yield. To further test effects of the mutant and wild-type strains of RNA 3 on sugar yield, deletion mutant T-3d4 and wild-type strain T-34 were inoculated to four different sugar beet cultivars (Monomidori, Monohikari, Ema, and Rizor). Isolate S-4, which does not contain any RNA 3, also was used as a control inoculum. Virus inoculation was done by pouring zoospore suspensions of viruliferous $P$. betae onto sugar beet seedlings grown in paper pots. At 10 days after inoculation, virus infection in rootlets of 10 seedlings per plot was checked by ELISA. The seedlings were transplanted and grown in the field. At harvest, the sugar beet root tips were sampled individually and the virus concentration was examined by ELISA. Some samples were also tested by northern blot hybridization tests as shown below. Groups of 40 roots per plot were tested on the yield parameters and the quality parameters.

Similar results, as described above, were obtained concerning symptom expression and virus detection in roots (Table 3 ). The wild-type virus T-34 caused foliage and root symptoms in all plants of the three susceptible cultivars and in only a few plants of the resistant cultivar. The severity of root symptoms also paralleled the susceptibility of the cultivars: Momomidori $>$ Monohikari $=$ Ema > Rizor. The symptom severity was strongly reflected in the yield (Table 3). With increasing susceptibility of the cultivars, root yield, sugar content, and sugar yield decreased (e.g., yield losses relative to the noninoculated control for each cultiver were Monomidori, 96\%; Monohikari, 78\%; Ema, 69\%; and Rizor, 22\%). For the quality parameters in roots of the susceptible plants, $\alpha$-amino acid nitrogen decreased and $\mathrm{Na}$ and $\mathrm{K}$ increased (data not shown). Thus, the wild-type virus caused a severe reduction in root weight and sugar content, depending on the susceptibility of the cultivar.

In contrast, the mutant strain $\mathrm{T}-3 \mathrm{~d} 4$ and isolate $\mathrm{S}-4$, which lacks RNA 3, caused no visible foliage and root symptoms in any of the cultivars (Table 3 ). When inoculated with T-3d4 or S-4, the sugar yields of roots in all four cultivars were almost the same as those of noninoculated control plants, although the virus was detected in most taproots (Table 3). No significant differences in the virus content in taproots were found between T-3d4 and S-4 or between susceptible and partially resistant cultivars (Table 3 ). In susceptible plants infected with wild-type BNYVV, on the other hand, the virus was detected in all taproots, and the virus content was much greater than that in those infected with the deletion mutants. In the resistant cultivar, however, the virus was detected in 23 out of 36 taproots $(64 \%)$, and the virus concentration was very low compared with that in susceptible plants (Table 3). Infection of deletion mutants did not affect the quality parameters (data not shown).

Northern blot hybridization tests. Northern blot hybridization tests for several taproots of two sugar beet cultivars were used in the above-mentioned experiments (Table 4). When inoculated with the wild-type virus (T-34), RNA 3 was always detected in taproots of sugar beet plants showing rhizomania symptoms, but was not detected in those showing no symptoms in taproots of the resistant plants, in which virus was detected by ELISA. However, when inoculated with the RNA 3 deletion mutant, the deleted RNA 3 was detected in roots of either susceptible or resistant plants. RNA 4 was detected from most of the roots. Reactions of cv. Rizor to T-34 infection appear to be divided into four types (Table 4): (i) positive root symptoms and replication of both RNAs 3 and 4; (ii) no root symptoms but positive replication of RNA 4; (iii) no root symptoms and no replication of RNA 3 or RNA 4, but still virus repli- 
cation positive; and (iv) no root symptoms and no virus replication. It seems that this is due to heterogeneity of the cv. Rizor or to differences in virus population in a root. However, RNA 3 was easily detected in rootlets of the resistant plants inoculated by $P$. betae at an early stage (data not shown).

\section{DISCUSSION}

In this study, we tested effects of BNYVV RNA 3 deletion mutant and wild-type viruses on symptom development and sugar yield in susceptible and partially resistant sugar beet cultivars. The two RNA 3 deletion mutants (S-3c and T-3d), which were selected from the isolates $\mathrm{S}$ and $\mathrm{T}$, lost 121 or 94 amino acid residues to the C-terminal parts of the P25 (219 amino acids). Although 11 amino acid changes (5\% differences) in the P25-coding region were observed between the two isolates, no amino acid changes in their coat protein were found (M. Miyanishi and T. Tamada, unpublished data), indicating that the two isolates used in this study are very similar. Symptoms produced in test plants (T. expansa and B. macrocarpa) by these mutants were much milder than those produced by wildtype strains. The RNA 3 deletion mutants were also efficiently transmitted by $P$ betae, when present together with RNA 4 . There were no differences in pathogenicity and transmissibility between two deletion mutants; therefore, the influence of about 30 amino acids at the C-terminus can be excluded.

In field-infected sugar beet, BNYVV is usually confined to the roots, in which the virus causes massive proliferation of fine rootlets and other abnormalities (so-called rhizomania) $(1,19)$. The appearance of shoot abnormalities such as yellowing is clearly associated with rootlet proliferation $(19,23)$. Typical symptoms can be observed in sugar beet plants inoculated with viruliferous $P$. betae, but it is difficult to induce the full spectrum of symptoms by mechanical inoculation $(7,15,23)$. Therefore, we investigated cultures carrying each isolate containing different mutant and wild-type viruses by inoculation with $P$. betae under laboratory and field conditions.

Our previous work has shown that BNYVV RNA 3 facilitates the multiplication and spread of the virus in root tissue and is associated with the production of rhizomania symptoms $(7,23)$. In this article, we provide further strong evidence that the P25, encoded by RNA 3, is responsible for the symptom development: isolates lacking about one-half of the P25-coding region did not induce rhizomania symptoms or affect sugar yield, whereas the wild-type virus caused severe symptoms and yield reduction, depending on the susceptibility of the sugar beet cultivars. A slight loss in root weight caused by the deletion mutant compared with the isolate lacking RNA 3 may be due to either an increase of the virus titer or the presence of the deleted RNA 3 itself. The mutant virus concentrations in roots were about $10 \times$ less than those of the wild-type virus; therefore, it is possible that, in field tests, the lack of rhizomania symptoms for the RNA 3 deletion mutants is due to the low virus concentration rather than being a direct consequence of the absence of P25. However, we show that abnormal rootlet proliferation does not always correlate with the virus content of roots. For example, such symptoms were not present in the rootlets of sugar beet seedlings infected with the RNA 3 deletion mutants, although the virus content in such roots was relatively high (23). Thus, we conclude that the presence (expression) of the P25 is not only associated with greatly increased virus titers in roots, but also is probably responsible for production of rootlet proliferation, one of the characteristics of rhizomania.

The involvement of RNA 3 in leaf symptoms has been discussed extensively by Jupin et al. (6,7), who showed by site-directed mutagenesis that the P25 is responsible for the yellow lesion (YS) phenotype on $T$. expansa leaves. It seems that this YS phenotype caused by expression of the P25 is closely correlated with rootlet proliferation in sugar beet plants. However, the isolates containing RNAs 4 and 5 also induce YS-type symptoms on T. expansa leaves
(24), but do not produce rootlet proliferation (22). It will be interesting to know which part of the P25 is involved in expression of such leaf or root symptoms.

In addition to an involvement of P25 in symptom development, we provide new information demonstrating that P25 may also be involved in the resistance mechanism of the partially resistant $\mathrm{cv}$. Rizor. If the wild-type virus infects rootlets of resistant sugar beet plants via the vector, the virus initially multiplies well in the root tissue, but subsequent virus movement to and multiplication in main roots are considerably inhibited as the sugar beet root system develops. A similar conclusion was also reached from histological evidence $(5,13,18)$. Northern blot hybridization revealed that RNA 3 was not detected in taproots of the resistant plants showing no symptoms, in which the virus was detected. In contrast, when infected with the deletion mutant, the virus movement to roots of the field-grown plants was not greatly inhibited, although the virus content was low. The deleted RNA 3 was also easily detected in the taproots. These results suggest the possibility that replication of the P25-coding RNA 3 molecule itself may be inhibited in taproots in resistant plants and, consequently, the wild-type virus containing RNA 3 fails to facilitate virus multiplication and movement in the roots. Clearly, the molecular mechanisms in this respect will require further study.

The fact that the mutant virus content of resistant plants was somewhat lower than that of susceptible plants may indicate that other genome factors, which are encoded by RNAs 1 and 2, such as in packaging, replication, or cell-to-cell movement $(15,19)$, may also be involved in a component of resistance. However, our data suggest that, if a second resistance component exists, its effect is small, because no differences in virus content of rootlets were found between the susceptible and resistant plants at an early stage.

\section{ACKNOWLEDGMENTS}

We thank K. Richards for the critical reading of the manuscript and B. Harrison for helpful suggestions.

\section{LITERATURE CITED}

1. Asher, M. J. C. 1993. Rhizomania. Pages 311-346 in: The Sugar Beet Crop: Science into Practice. D. A. Cooke and R. K. Scott, eds. Chapmann and Hall, London.

2. Buttner, G., and Burcky, K. 1990. Content and distribution of beet necrotic yellow vein virus (BNYVV) in sugar beet varieties with different degrees of susceptibility to rhizomania. Pages 83-86 in: Proc. Symp. Int. Working Group on Plant Viruses with Fungal Vectors, 1st. R. Koenig, ed. Eugen Ulmer, Stuttgart, Germany.

3. de Biaggi, M. 1987. Methodes de delection-un cas concret. Pages 157161 in: Proc. Winter Congr. Symp. Int. Inst. Sugar Beet Res. (IIBR), 50th. IIBR, Brussels, Belgium.

4. Giunchedi, L., de Biaggi, M., and Poggi-Pollini, C. 1987. Correlation between tolerance and beet necrotic yellow vein virus in sugar-beet genotypes. Phytopathol. Mediterr. 26:23-28.

5. Giunchedi, L., and Poggi-Pollini, C. 1988. Immunogold-silver localization of beet necrotic yellow vein virus antigen in susceptible and moderately resistant sugar beets. Phytopathol. Mediterr. 27:1-6.

6. Jupin, I., Guilley, H., Richards, K. E., and Jonard, G. 1992. Two proteins encoded by beet necrotic yellow vein virus RNA-3 influence symptom phenotype on leaves. EMBO (Eur. Mol. Biol. Organ.) J. 11:479-488.

7. Jupin, I., Tamada, T., and Richards, K. 1991. Pathogenesis of beet necrotic yellow vein virus. Semin. Virol. 2:121-129.

8. Kiguchi, T., Saito, M., and Tamada, T. 1996. Nucleotide sequence analysis of RNA-5 of five isolates of beet necrotic yellow vein virus and the identity of a deletion mutant. J. Gen. Virol. 77:575-580.

9. Koenig, R., Jarausch, W., Li, Y., Commandeur, U., Burgermeister, W., Gehrke, M., and Luddecke, P. 1991. Effect of recombinant beet necrotic yellow vein virus with different RNA compositions on mechanical inoculation of sugarbeets. J. Gen. Virol. 72:2243-2246.

10. Masuta, A. 1986. Latest development in sugar beet transplanting techniques in Japan. Pages 201-221 in: Proc. Winter Congr. Symp. Int. Inst. Sugar Beet Res. (IIBR), 49th. IIBR, Brussels, Belgium.

11. Miyanishi, M., Kusume, T., Saito, M., and Tamada, T. 1999. Evidence 
for three groups of sequence variants of beet necrotic yellow vein virus RNA 5. Arch. Virol. 144:879-892.

12. Paul, H., Henken, B., and Alderlieste, M. F. J. 1992. A greenhouse test for screening sugar-beet (Beta vulgaris) for resistance to beet necrotic yellow vein virus (BNYVV). Neth. J. Plant Pathol. 98:65-75.

13. Poggi-Pollini, C., and Giunchedi, L. 1989. Comparative histopathology of sugar beets that are susceptible and partially resistant to rhizomania. Phytopathol. Mediterr. 28:16-21.

14. Richard-Molard, M. 1985. Rhizomania: A world-wide danger to sugar beet. Span 28:92-94.

15. Richards, K. E., and Tamada, T. 1992. Mapping functions on the multipartite genome of beet necrotic yellow vein virus. Annu. Rev. Phytopathol. 30:291-313.

16. Saito, M., Kiguchi, T., Kusume, T., and Tamada, T. 1996. Complete nucleotide sequence of the Japanese isolate $\mathrm{S}$ of beet necrotic yellow vein virus RNA and comparison with European isolates. Arch. Virol. 141:2163-2175.

17. Saito, M., Kiguchi, T., and Tamada, T. 1997. Nonradioactive, digoxigenin-labeled DNA probes for the detection of five RNA species present in beet necrotic yellow vein virus. Bull. Res. Inst. Bioresour. Okayama Univ. 5:79-96.

18. Scholten, O. E., Paul, D., van Lent, J. W. M., and Goldbach, R. W. 1994. In situ localization of beet necrotic yellow vein virus (BNYVV) in rootlets of susceptible and resistant beet plants. Arch. Virol. 136:349-361.

19. Tamada, T. 1999. Benyviruses. Pages 154-160 in: Encyclopedia of Virol- ogy. 2nd ed. R. G. Webster and A. Granoff, eds. Academic Press, London.

20. Tamada, T., and Abe, H. 1989. Evidence that beet necrotic yellow vein virus RNA-4 is essential for efficient transmission by the fungus Polymyxa betae. J. Gen. Virol. 70:3391-3398.

21. Tamada, T., and Kusume, T. 1991. Evidence that the $75 \mathrm{~K}$ readthrough protein of beet necrotic yellow vein virus RNA-2 is essential for transmission by the fungus Polymyxa betae. J. Gen. Virol. 72:1497-1504.

22. Tamada, T., Kusume, T., Uchino, H., Kiguchi, T., and Saito, M. 1996. Evidence that beet necrotic yellow vein virus RNA-5 is involved in symptom development of sugar-beet roots. Pages 49-52 in: Proc. Symp. Int. Working Group on Plant Viruses with Fungal Vectors, 3rd. J. L. Sherwood and C. M. Rush, eds. American Society of Sugar Beet Technologists, Denver.

23. Tamada, T., Saito, M., Kiguchi, T., and Kusume, T. 1990. Effect of isolates of beet necrotic yellow vein virus with different RNA components on the development of rhizomania symptoms. Pages 41-44 in: Proc. Symp. Int. Working Group on Plant Viruses with Fungal Vectors, 1st. R. Koenig, ed. Eugen Ulmer, Stuttgart, Germany.

24. Tamada, T., Shirako, Y., Abe, H., Saito, M., Kiguchi, T., and Harada, T. 1989. Production and pathogenicity of isolates of beet necrotic yellow vein virus with different numbers of RNA components. J. Gen. Virol. 70:3399-3409.

25. Tuitert, G., Muster-van Oorschot, P. M. S., and Heijbroek, W. 1994 Effect of sugar beet cultivars with different levels of resistance of beet necrotic yellow vein virus on transmission of virus by Polymyxa betae. Eur. J. Plant Pathol. 100:201-220. 